\title{
Influence of water quality on fish productivity
}

\author{
M. A. El Bably ${ }^{1 *}$, H. H. Emeash ${ }^{1}$, Asmaa N. Mohamed ${ }^{1}$, Nahla R. ${ }^{2}$ \\ ${ }^{I}$ Department of Hygiene, Management and Zoonoses, Faculty of Veterinary Medicine, Beni-Suef \\ University and ${ }^{2}$ Department of Fish Diseases, Animal Health Research Institute, Dokki, Giza, Egypt
}

\begin{abstract}
The physical, chemical and bacteriological parameters of water in fish ponds were investigated with a view to optimize the conditions for fish productivity by using three private fish farms with different water supplies. Water and fish samples were collected equally from each pond over a period of 17 months. Water temp., Dissolved oxygen (DO), pH, Ammonia, Nitrite, Nitrate, and bacterial count were determined. The average values of bacterial, parasitic, survival and growth rates of fish were also assessed. Results revealed that pond water in farm (III) had the highest averages of temperature nitrite, nitrate $31.8 \pm 1.5,8.18 \pm 0.9,0.41 \pm 0.06,3.79 \pm 0.6$ resp., with the least content of DO $3.6 \pm 0.7$ followed by farm (II), which had also the highest mean values of $\mathrm{NH}_{3}$ - $\mathrm{N}$, total coliform and fecal coliforms were $3.15 \pm 0.65,59.0 \& 18.5$ followed by ponds of farm (III), while, the lowest averages of estimated parameters were recorded in farm (I).Correspondingly, fish samples of farm (III) showed the highest level of total bacterial, coliform, fecal coliform count and parasitic infestation; were 42.5 $\pm 5.4,29.6 \pm 3.6,11.3 \pm 3.1$ and $31.15 \%$ respectively, followed by fish of farm(II) 29.75 $\pm 3.5,11.5 \pm 3.3,7.4 \pm 1.1$ and $10.8 \%$ respectively, Meanwhile, fish in farm (I) showed the lowest value of both bacterial contents with no parasitic infestation which explain the highest percentages of daily weight gain \& survival rates $35.2 \pm 4.4 \mathrm{gm}$. \& $97.0 \pm 1.6 \%$ respectively. Throughout study period compared with those in farms (III \& II) respectively, resulting from poor water quality \& parasitic infestation which acts as stressors affecting fish health and productivity. Therefore, fish productivity can be enhanced if the water quality in the ponds were maintained at optimum levels.
\end{abstract}

The fish farming under optimum conditions can offers an alternative solution to the increasing market demand for fish and fish protein, in addition to providing a viable source of revenue for most households with proper water management practices (Lewbart, 2001).The total Egyptian fish production reached about 960 thousand tons in 2006, of which more than $61 \%$ was from aquaculture (Gafrad, 2007). The main cultured species are tilapia (O.niloticus); Carps (Cyprinus carpio), mullets and the African catfish (Clarias gariepinus). Tilapia are the most popular fish in Egypt for their favorable characteristics and production, whether from the wild water bodies or from the aquaculture (El-Shafai et al., 2004). Good fish management begins with an understanding of the physical, chemical and biological characteristics of the ponds. These characteristics determine the quality of fish the ponds can produce and the problems that may be encountered (Felix et al., 2008). All other things being equal, a pond with "good" water quality will produce more and healthier aquatic creatures than a pond with "poor" water quality. Water quality parameters such as ammonia and nitrite in fish ponds may

* Corresponding author. Tel.: +20 082 2322066;

Fax: +20 0822327982

E-mail address: drelbably97@yahoo.com

(Mohamed A. Elbably) affect the level of bacterial contamination of fish organs (Saed and Sakr, 2009). This is probably due to the effect of water quality on the fish immune response .A number of research studies have been done on fish ponds., all pointing to the fact that all factors in the fish pond ecosystem are inter-related and require proper understanding in order to improve productivity (Kweilin and Yang, 2003). Profitable fishing can result from proper management of fish and ponds. The type and level of bacterial populations associated with farmed fish are useful indicators of quality and safety of fish for consumers, of much concern in ponds is the contamination of fishes by fecal coliform, (Kapetanovic et al., 2005). Their presence in fish may cause a potential danger for human health (Prithwiraj and Barat, 2008).Therefore, the aim of the present study therefore was to establish the levels of physico-chemical and biological characteristics of the ponds with a view to optimizing the conditions of water for optimum fish productivity.

\section{Materials and methods}

The effects of water quality were tested over a period of 17 months from April 2006 till the end of September 2007 in three fish farms located at governorates of Behera (I\&II) and 
Menioufia (III. Three water sources with different qualities were used; Brackish, Agriculture and Underground water respectively. Tilapia niloticus were the only species cultured in farms I \& II, while ponds in farm III contains 3 different species; carp and Claris Lazera with stocking densities of 10.5, 14.6 and $18.2 \mathrm{~lm}$ respectively in examined farms.

Study site.

Farm (I). It contains one earthen pond with average size of $180 \times 42 \mathrm{~m}$ and depth $1.4 \mathrm{~m}$.Fish fed on commercial pelletted ration contains $27 \%$ protein. Pond water was exchange twice /week Farm (II). It contains two earthen ponds of average dimensions of 150 X $50 \mathrm{~m} \&$ depth of $1.2 \mathrm{~m}$. Fish fed on pelletted ration processed in the farm and contains $22 \%$ protein. Water exchange was done three times /week.

Farm (III. It belongs to the French village and contains two circular shaped concrete ponds; with average sizes of $80 \times 70 \mathrm{~m} \&$ depth $1.2 \mathrm{~m}$ for each. Fish fed on commercial ration contain $25 \%$ protein and pyrogen as feed additives to improve performance. Water was renewed only to compensate for losses by evaporation and infiltration, and when oxygen levels were lower than $4 \mathrm{mg}$

Sampling program. 200 water samples were collected from both supplies \& ponds besides 225 fish samples were collected equally from 3 examined farms throughout the study period. The collected samples were transferred with a minimum delay to Department of Fish Diseases in Animal Health Research Institute, Dokki for further investigation

Sampling of water. Water samples were taken from two locations for each pond: close to the pond inlet besides center of each pond .Samples were collected weekly at a fixed hour of the day $(9.0 \mathrm{~h})$ as described earlier by (Boyd, 1998). Results were averaged monthly.

Physico-chemical analyses of water samples. Routine water quality parameters for temperature, DO, $\mathrm{pH}, \mathrm{NH} 3-\mathrm{N}, \mathrm{NO} 2-\mathrm{N}, \mathrm{NO} 3-\mathrm{N}$, Alkalinity and salinity were estimated according to methods as described by (APHA, 1998). Temperature was recorded using a mercury thermometer. The $\mathrm{pH}$ was measured in situ using a portable $\mathrm{pH}$ meter (Hanna Instruments) The dissolved oxygen (DO) was determined using the YSI DO metering with polarographic Sensor probes, Ammonia (UIA-N), $\mathrm{NO}_{2}-\mathrm{N}$ and NO3-N concentrations were estimated using commercial kits; the alkalinity was determined using the alkalinity test kit while Salinity (mg/l) was determined by hand refractometer- (ColeParmer instrument Co- Atago-60648- ChicagoUSA).

Bacteriological analysis of water samples. Water samples were collected weekly in presterilized glass bottles $(250 \mathrm{ml})$. samples were used for total bacterial count, total coliform and faecal coliform measurement according to the protocol provided in standard method for the examination of water and waste water analysis by (APHA, 1998)

The total viable aerobic mesophile counts were carried out on plate-count agar (PCA, Oxoid, UK) and nutrient agar (NA) while total coliforms and fecal coliforms were enumerated on MacConkey agar according to method described (Cruickshan et al., 1972).

Sampling of fish. A cast net used to collect fish samples from the various ponds. For each pond, five live tilapia (Oreochromis niloticus) were randomly selected from the catch at each sampling time as method described by (AOAC, 1999).The fish were placed in labeled sterile polypropylene bags containing water from the pond and transported to the laboratory.

Bacteriological examination of fish samples. Fish samples were used for total bacterial count, total coliform and faecal coliform measurement according to the protocol provided in standard method for the examination of water and waste water analysis by (APHA, 1998). Surface swabs of each fish were made upon arrival at the laboratory.

Parasitological examination of fish. Parasitological examination for detection of external parasite infestation was carried out according to method done by (Abd El Khalek, 1998).

Fish performance. Averages of initial live body weight and survival rates were recorded and then biweekly fish weight $(0.01 \mathrm{~g})$ of fish from each pond (average of 5 fish / pond) was measured. However, the other parameters were calculated after (Hargreaves and Semra, 2001).

Body weight gain. Daily weight gain $\%=100$ (final weight $(\mathrm{g})$ - initial weight $(\mathrm{g}) /$ initial weight ( $\mathrm{g}$ ) as method recommended by (Bhikajee and Gobin, 1998).

Survival rate. Survival $\%=(\mathrm{Nf} / \mathrm{Ni}) \times 100$.

Where $\mathrm{Nf}$ and $\mathrm{Ni}$ are the number of fish harvested and stocked respectively, according to method done by (Etienne et al., 2001).

Statistical analysis. All numerical collected data were statistically analyzed using one way ANOVA ( $\mathrm{F}$ test \& $\mathrm{T}$ Test) according to 
(Snedecor and Cochran, 1989).

\section{Results and discussion}

The average values of physio-chemical parameters of water close to pond inlet in the three examined farms as shown in Table (1) revealed that, underground supply of farm (III) showed the highest values of water temperature, $\mathrm{pH}$, nitrite, nitrate and total alkalinity $31.8 \pm 1.5$, $8.18 \pm 0.9,0.41 \pm 0.06,3.79 \pm 0.6,54.7 \pm 2.3$ respectively with the minimal content of dissolved oxygen (DO) $3.6 \pm 0.7$ followed by mean values in farm (II) were $30.4 \pm 1.1,8.1 \pm$ $1.1,3.15 \pm 0.65,0.35 \pm 0.06,0.83 \pm 0.25$ and 43.3 respectively. On the other hand; agriculture water supply farm (II) had the highest contents of total coliform and fecal coliforms counts 59.0 \& 18.5 followed by 13.8 \& ND in farm (III). Meanwhile, brackish water supply in farm (I) had the lowest averages of physico-chemical and bacterial values except those for DO content and salinity were 6.8 and $65.0 \mathrm{mg} / 1$ resp., compared with other farms

The above results of physio-chemical parameters of water from different water sources were within average suitable range for Tilapia culture except ammonia in farm (II) ; nitrite, nitrate for ground water in farm (III). This finding was further supported by (Okonji and Akolisa, 2005; Frei et al., 2006).

Data for physico-chemical and microbiological analyses of water samples taken from fishponds (Table 2) indicated that farm (III) had the highest values of water temperature, $\mathrm{pH}$, nitrite, nitrate and total alkalinity $31.8 \pm 1.5$, $8.18 \pm 0.9,0.41 \pm 0.06,3.79 \pm 0.6,54.7 \pm 2.3$ respectively with the minimal content of dissolved oxygen (DO); $3.6 \pm 0.7$ followed by averages values in farm (II) were $30.4 \pm 1.1$, $8.1 \pm 1.1,3.15 \pm 0.65,0.35 \pm 0.06,0.83 \pm 0.25$ and 43.3 respectively, meanwhile; the highest level of total coliform and fecal coliforms were in Farm (II) ; 59.0 \& 18.5 followed by 13.8 \& ND in farm (III) On the other hand, the lowest average values were recorded in farm (I) except DO content and salinity were 6.8 and $65.0 \mathrm{mg} / 1$ resp.,The obtained results indicates that water supply have direct effect on physical, chemical and bacteriological quality of pond water as agriculture water tends to increase the averages of total coliform and fecal coliform counts .Moreover, it is apparent that water in farm II \& III present unsuitable environment for fish health, growth and production. This result was in accordance with (Wickens, 2006)
The results of the quantitative estimation of bacterial level of fish samples (Table 3 ) show the mean values of, it was evident that the highest values of total bacterial, total coliform and fecal coliform counts were recorded in farm (III); $42.5 \pm 5.4,29.6 \pm 3.6 \& 11.3 \pm 3.1$ resp., followed by fish in farm (II) $29.75 \pm 3.5,11.5 \pm 3.3$ \& $7.4 \pm 1.1$ resp., and the lowest values was recorded in farm( I), The increase of bacterial loads of fish may be attributed to significant increase in water NO2-N ,NO3-N and minimal DO contents (Farm III) and significant increase of NH3-N (Farm II). Similar result was obtained by (Saed and Sakr 2009; Abu El -Wafa, 1988; Al-Harbi, 2003) explained that poor water quality may have induced weakness in the fish, resulting in a greater susceptibility to bacterial infection.

Results in Table (4) showed the percentage of fish infestation with external parasite in examined farms shows. it ranged from 0 (Farm I) to $31.5 \%$ (Farm III).Trichodina was the prevalent ectoparasites in farms (I \& II), 66.0 \pm 3.2 , followed by Monogenia, mixed infection \& epistylis were $51.0 \pm 3.7,17.5 \pm 2.0$ \& $13.5 \pm 2.75$ respectively .Results indicates a significant correlations between parasitic infestation with water temperature, Do content, NO3-N, NO2-N \& bacterial contaminants in (Farm III) \& NH3-N, total and fecal coliform counts (Farm II) similar results obtained by (Nahla, 1989; Abd El Khalek 1998; Frei et al., 2007).

The average percentage of body weight gain and survival rates of fish in examined farms at harvest is presented in( Table 5), it is evident that Farm (I) having the highest averages 35.2 and $97.0 \%$ respectively, followed by $28.5 \pm 3.5 \&$ $89.0 \pm 2.0$ resp., in farm(III) with the lowest values $22.5 \pm 3.5 \& 85.8 \pm 2.7$ respectively, (farm III). High fish productivity obtained in farm (I) could be attributed to the favourable physicochemical \& bacterial conditions of water besides absence of parasitic infestation within fish ponds this, in contrast with the prevailing physicochemical, bacteriological and parasitic stressors in ponds of farms III and II respectively. The obtained results in accordance with (George, 1999; Alejandro et al., 2000). Moreover, Saed and Sakr, (2009) concluded that the health status of tilapia fish reared in brackish water not affected by increasing in salinity .Moreover the rate of fish stocking densities and the level and type of parasite infestation, body weight gain (\%) and survival rates of fishes in examined 
Table (1): The average values of phyisco-chemical and bacteriological findings of different water supplies in three examined fish farms.

\begin{tabular}{|c|c|c|c|c|}
\hline \multirow[t]{2}{*}{ Water parameters } & & \multicolumn{3}{|c|}{ Farms } \\
\hline & & I & II & III \\
\hline \multirow[t]{8}{*}{ Physicochemical } & Temperature $\left({ }^{0} \mathrm{C}\right)$ & $28.50 \pm 1.00$ & $29.00 \pm 1.20$ & $28.70 \pm 1.50$ \\
\hline & Dissolved oxygen (mg/l) & $7.10 \pm 0.50^{\mathrm{a}}$ & $5.80 \pm 1.03^{b}$ & $5.20 \pm 0.70^{b}$ \\
\hline & $\mathrm{pH}$ & $7.50 \pm 0.50$ & $7.80 \pm 0.80$ & $7.80 \pm 1.00$ \\
\hline & $\mathrm{NH}_{3}-\mathrm{N}(\mathrm{mg} / \mathrm{l})$ & $0.07 \pm 0.04^{\mathrm{c}}$ & $0.86 \pm 0.12^{\mathrm{a}}$ & $0.16 \pm 0.07^{\mathrm{b}}$ \\
\hline & $\mathrm{NO}_{2}-\mathrm{N}(\mathrm{mg} / \mathrm{l})$ & $0.20 \pm 0.17^{\mathrm{b}}$ & $0.22 \pm 0.06^{\mathrm{b}}$ & $1.83 \pm 0.82^{\mathrm{a}}$ \\
\hline & $\mathrm{NO}_{3}-\mathrm{N}(\mathrm{mg} / \mathrm{l})$ & $0.06 \pm 0.03^{c}$ & $0.27 \pm 0.15^{b}$ & $8.50 \pm 0.28^{a}$ \\
\hline & Total Alkalinity $(\mathrm{mg} / \mathrm{l})$ as $\mathrm{CaCO}_{3}$ & $50.70 \pm 2.80^{b}$ & $53.70 \pm 2.30^{\mathrm{b}}$ & $60.30 \pm 2.60^{\mathrm{a}}$ \\
\hline & Salinity $(\mathrm{mg} / \mathrm{l})$ & $63.00 \pm 3.00^{\mathrm{a}}$ & $40.70^{\mathrm{b}} \pm 3.00$ & $48.00 \pm 3.60^{b}$ \\
\hline \multirow[t]{3}{*}{ Bacterial Finding } & T.B.C. $(\mathrm{x} 103)$ & $3.40 \pm 2.00^{\mathrm{c}}$ & $10.60 \pm 3.00^{\mathrm{a}}$ & $5.80 \pm 1.00^{b}$ \\
\hline & Total Colifom T.C ( /100ml). & $<3.00$ & $23.40 \pm 3.80$ & $<3.00$ \\
\hline & Faecal Coliform $(/ 100 \mathrm{ml})$. & ND & ND & ND \\
\hline
\end{tabular}

Results are expressed as mean \pm S.E.

$\mathrm{a}, \mathrm{b}$ and $\mathrm{c}$ superscripts within rows differ significantly at $\mathrm{p}<0.05$

ND: Non-detected

Table (2): The average values of phyisco-chemical and bacteriological findings of different ponds water in three examined fish farms.

\begin{tabular}{|c|c|c|c|c|}
\hline \multirow[t]{2}{*}{ Water parameters } & & \multicolumn{3}{|c|}{ Farms } \\
\hline & & I & II & III \\
\hline \multirow[t]{8}{*}{ Physicochemical } & Temperature $\left({ }^{0} \mathrm{C}\right)$ & $29.50 \pm 1.60^{b}$ & $30.40 \pm 1.10^{b}$ & $31.80 \pm 1.50^{\mathrm{a}}$ \\
\hline & Dissolved oxygen $\quad(\mathrm{mg} / \mathrm{l})$ & $6.80 \pm 0.50^{\mathrm{a}}$ & $4.90 \pm 0.61^{\mathrm{b}}$ & $3.60 \pm 0.70^{\mathrm{b}}$ \\
\hline & $\mathrm{pH}$ & $7.80 \pm 1.00$ & $8.10 \pm 1.10$ & $8.18 \pm 0.90$ \\
\hline & $\mathrm{NH}_{3}-\mathrm{N} \quad(\mathrm{mg} / \mathrm{l})$ & $0.15 \pm 0.03^{c}$ & $3.15 \pm 0.65^{\mathrm{a}}$ & $2.26 \pm 0.50^{b}$ \\
\hline & $\mathrm{NO}_{2}-\mathrm{N} \quad(\mathrm{mg} / \mathrm{l})$ & $0.32 \pm 0.10^{\mathrm{a}}$ & $0.16 \pm 0.06^{\mathrm{b}}$ & $0.41 \pm 0.06^{\mathrm{a}}$ \\
\hline & $\mathrm{NO}_{3}-\mathrm{N}(\mathrm{mg} / \mathrm{l})$ & $0.40 \pm 0.07^{b}$ & $0.83 \pm 0.25^{b}$ & $3.79 \pm 0.60^{\mathrm{a}}$ \\
\hline & Total Alkalinity $(\mathrm{mg} / \mathrm{l})$ as $\mathrm{CaCO}_{3}$ & $40.30 \pm 3.00^{b}$ & $43.30 \pm 2.80^{b}$ & $54.70 \pm 2.30^{\mathrm{a}}$ \\
\hline & Salinity $(\mathrm{mg} / \mathrm{l})$ & $65.00 \pm 4.00^{\mathrm{a}}$ & $38.90 \pm 2.90^{\mathrm{c}}$ & $50.90 \pm 2.90^{b}$ \\
\hline \multirow[t]{3}{*}{ Bacterial Finding } & T.B.C. $\left(\times 10^{3}\right)$ & $7.80 \pm 1.80^{\mathrm{c}}$ & $29.75 \pm 2.35^{b}$ & $42.5 \pm 1.50^{\mathrm{a}}$ \\
\hline & TotalColifom ( / 100ml $)$ & $3.0 \pm 1.10^{\mathrm{c}}$ & $59.00 \pm 4.40^{\mathrm{a}}$ & $13.80 \pm 4.00^{\mathrm{b}}$ \\
\hline & Faecal coliform $(/ 100 \mathrm{ml})$ & ND & $18.5 \pm 3.9$ & ND \\
\hline
\end{tabular}

Results are expressed as mean \pm S.E.

$\mathrm{a}, \mathrm{b}$ and c superscripts within rows differ significantly at $\mathrm{p}<0.05$

ND: Non-detected

Table (3): The average values of bacterial findings of fish samples in three examined fish farms.

\begin{tabular}{lccc}
\hline \multirow{2}{*}{ Bacterial findings } & \multicolumn{3}{c}{ Farms } \\
\cline { 2 - 4 } & I & II & III \\
\hline Total viable bacterial count T.B.C. $\left(\times 10^{3}\right)$ & $7.80 \pm 1.80^{\mathrm{c}}$ & $29.75 \pm 3.50^{\mathrm{b}}$ & $42.50 \pm 5.40^{\mathrm{a}}$ \\
Total Coliform $(/ 100 \mathrm{ml})$ & $3.0 \pm 1.10^{\mathrm{c}}$ & $11.50 \pm 3.30^{\mathrm{b}}$ & $29.60 \pm 3.60^{\mathrm{a}}$ \\
Fecal Coliform $(/ 100 \mathrm{ml})$ & $\mathrm{ND}$ & $7.40 \pm 1.10^{\mathrm{b}}$ & $11.30 \pm 3.10^{\mathrm{a}}$ \\
\hline
\end{tabular}

Results are expressed as mean \pm S.E. ND: Non-detected.

$\mathrm{a}, \mathrm{b}$ and $\mathrm{c}$ superscripts within rows differ significantly at $\mathrm{p}<0.05$

Table (4): The average distribution of external parasite infestation (\%) of fish samples in examined farms.

\begin{tabular}{lccccc}
\hline Farms & \multicolumn{5}{c}{ Parasitic infestation } \\
\cline { 2 - 6 } & $\begin{array}{c}\text { \% of } \\
\text { infestation }\end{array}$ & Trichodina & Monogenia & Epistylis & Mixed infection \\
\cline { 2 - 6 } & ND & ND & ND & ND & ND \\
I & 10.80 & $22.00 \pm 3.00^{\mathrm{b}}$ & $8.00 \pm 2.00^{\mathrm{b}}$ & $5.00 \pm 1.50^{\mathrm{b}}$ & $12.00 \pm 2.50^{\mathrm{b}}$ \\
II & 31.15 & $44.00 \pm 3.50^{\mathrm{a}}$ & $43.00 \pm 4.50^{\mathrm{a}}$ & $12.50 \pm 2.50^{\mathrm{a}}$ & $15.00 \pm 3.00^{\mathrm{a}}$ \\
III & 21.00 & $66.00 \pm 3.20$ & $51.00 \pm 3.70$ & $17.50 \pm 2.00$ & $13.50 \pm 2.75$ \\
Total & &
\end{tabular}

Results are expressed as mean \pm S.E.

$\mathrm{a}, \mathrm{b}$ and $\mathrm{c}$ superscripts within columns differ significantly at $\mathrm{p}<0.05$

ND: Non-detected.

Table (5): Relationship between stocking density and parasitic infestation of the three examined fish farms with fish performance.

\begin{tabular}{lccc}
\hline \multicolumn{1}{c}{ Parameters } & \multicolumn{1}{c}{ Farms } & III \\
\cline { 2 - 4 } & I & II & $18.20 \pm 1.80^{\mathrm{a}}$ \\
\hline Stocking density / $\mathrm{m}^{3}$ & $10.50 \pm 2.50 \mathrm{c}$ & $14.60 \pm 3.40^{\mathrm{b}}$ & $31.15 \pm 4.50^{\mathrm{a}}$ \\
Parasitic infestation (\%) & ND & $10.80 \pm 2.70^{\mathrm{b}}$ & $7.10 \pm 2.00$ \\
Initial body weight (g) & $7.10 \pm 2.60$ & $6.50 \pm 2.00$ & $162.00 \pm 4.00^{\mathrm{c}}$ \\
Final body weight (g) & $218.80 \pm 8.00^{\mathrm{a}}$ & $185.00 \pm 4.00^{\mathrm{b}}$ & $22.5 \pm 3.50^{\mathrm{c}}$ \\
Body weight gain (\%) & $35.20 \pm 4.40^{\mathrm{a}}$ & $28.50 \pm 3.50^{\mathrm{b}}$ & $85.80 \pm 2.70^{\mathrm{b}}$ \\
Survival rate (\%) & $97.00 \pm 1.60^{\mathrm{a}}$ & $89.00 \pm 2.00^{\mathrm{b}}$ & \\
\hline
\end{tabular}

Results are expressed as mean \pm S.E.

$\mathrm{a}, \mathrm{b}$ and $\mathrm{c}$ superscripts within rows differ significantly at $\mathrm{p}<0.05$

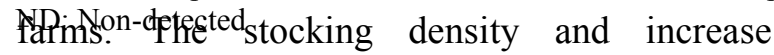


bacterial content and parasitic infestation as shown in fish of farms (III) followed by farm (II) resp., These results were in accordance with Shehata (1993) concluded a marked effect of the stocking rates and water quality on the specific growth rate during the whole growing season. Moreover, Amoako, (2006); Abdel Tawab and Sweilum, (2004) attributed increasing of fish mortalities in ponds with low dissolved oxygen and high nitrite contents due to increase the levels of bacterial and parasitic infestation

From the aforementioned results, it can be concluded that, water quality parameters in fish ponds affect the level of both bacterial contamination and ectoparasite infestation of fish. This is probably due to the effect of water quality on the fish performance which in turn reduces fish productivity. Commonly, a pond with good water quality will produce more and healthier fish than a pond with poor quality.

\section{References}

Abd El Khalek, H. M. (1998): Studies on the ectoparasites of some freshwater fishes in Beni- Suef Governorate. M.V.Sc. Thesis. Fac. Vet. Med., Beni- Suef, Cairo Univ.

Abdel Tawab, A. A. and Sweilum , M. A. (2004): Improvement of fish production and water quality in Tilapia cultured ponds by using different types of artificial diets and organic fertilizers. Vet .Med .J.Giza, Vol 52, No .1: 19 -28.

Abu EI Wafa, S. A. D. (1988): Protozoal-parasites of some fresh water fish in Behera Governorate. M.V.Sc. Thesis, Fac.Vet. Med., Alexandria University.

Alejandro, B. J.; Delbert, M.; Gatlin, M., and William, H. N. (2000): Effect of water temperature and Dissolved oxygen on daily feed consumption, feed utilization and growth of Channel Cat Fish (Ictalurus punctatus). Aquaculture 182: 339 - 352 .

Al - Harbi , A. H. (2003): Faecal coliforms in pond water, sediments and hybrid tilapia Oreochromis niloticus $\times$ Oreochromis aureus in Saudi Arabia . Aquaculture Research, 34 (7): 517-524, June.

Al-Harbi, A. H. and Naim uddin, M. (2003): Quantitative and qualitative studies on bacterial flora of hybrid tilapia (Oreochromis niloticus $\times$ Oreochromis aureus) cultured in earthen ponds in Saudi Arabia. Aquaculture Research, 34: $34-48$.

Amoako, M. (2006): Infestation of ectoparasites on Nile tilapia (Oreochromis niloticus) in aquaculture production in the Ashanti region, Ghana.

AOAC; Association of Official Analytic Chemists (1999): Official Methods of analysis. $16^{\text {th }}$ Edn. MD. USA.

APHA (American Public Health Association) (1998): Standard Methods for the Examination of water and waste water. $20^{\text {th }}$ edn. A.P.H.A., Washington, D.C. USA.

Bhikajee, M. and Gobin , P. (1998): Effect of temperature on the feeding rate and growth of red tilapia hybrid tilapia Aquaculture . Proceedings from the 4th International Symposium on Tilapia. Aquaculture, Vol. 1 , pp. $131-140$.

Boyd, C. E. (1998): Water quality and Pond soil analysis for Aquaculture. Auburn University, Auburn, Alabama, 183 pp.
Cruickshank, R.; Duduid, J. P. and Swain, R. H. A. (1972): Handbook of bacteriology. 11th Ed. E. and S. Livingstone limited Edinburgh and London.

El-Shafai, S. A.; El-Gohary, F. A.; Nasr, F. A. and Gijzen, H. J. (2004): Microbial quality of tilapia reared in fecal-contaminated ponds. Environmental Research, 2004 (Vol. 95) (No. 2) 231-238.

El-Shafai, S.A.; El Gohary, F. A.; Nasr, F. A.; Peter, N. S. and Huub, J. G. (2004): Chronic ammonia toxicity to duckweed fed tilapia (Oreochromis niloticus). Aquaculture 232: $117-127$.

Etienne, B. A.; Bruno, J. and Charles, M. (2001): Effect of water temperature on survival, growth and phenotypic sex of mixed (XX- XY) progenies of Nile tilapia Oreochromis niloticus. Aquaculture, 192: 187 - 199.

Felix W. N. and Mojisola O.E. (2008): Physicochemical and microbiological characteristics of water for fish production using small ponds .Physics and chemistry of the Earth 33; 701-707

Frei, M.; Makhan, M. A.; Razzak, M. A. and Hossan, M. M. (2007): Effect of a mixed culture of Common Carp , Cyprinus Carpio (L) and Nile tilapia, Oreochromis niloticus (L) on terrestrial arthropod population in rice field systems in Bangladesh. Biological Control, 41: 207 - 221.

Frei, M.; Razzak, M. A.; Hossain, M. M. and Oehme, M. (2006): Performance of common carp, Cyprinus Carpio and Nile tilapia, Oreochromis niloticus (L) in integrated ricefish culture in Bangladesh. Aquaculture, 11: 619 - 627.

GAFRAD (General Authority for Fishery Resources Development) (2007): Year-Book of fishery statics in Egypt (1990-2007), Cairo

George, T. T. (1999): Observations on the growth of tilapia nilotica 1. In Tropical Freshwater Fish Ponds Treated With Different Fertilizers. FAO/CIFA Symposiumon Aquaculture in Africa 30 Sept - 2 Oct 1999 Accra, Ghana CIFA / 95 SE 11.

Hargreaves, J. A. and Semra, K. (2001): Effect of dial unionized ammonia fluctuation on juvenile hybrid striped bass, channel cat fish and blue Tilapia. Aquaculture 195: $163-181$.

Herrison, C. K.; Hans, K. S. and Henk, B. (2007): The parasites and environmental factors affecting growth of Nile tilapia (O.niloticus) Juveniles. Aquaculture, 255: 586 596.

Khalid, H. Z.; Wafaa, S. H.; Iman, A. Z. and Mohamed, A. M. (2007): Ecological and biological studies on the Nile tilapia Oreochromis niloticus in Lake Burullus. Egyptian.J. Aqu. Biol and Fisheries Vol 11(3): 212-223.

Kweilin, C. and Yang, Y. (2003): Minimizing environmental impact of freshwater aquaculture and reuse of pond effluents and mud. Aquaculture, 226 (31) $57-65$.

Lewbart, G. (2001): Water quality and its impact on diseases of fish. In: Proceedings pf the Atlantic Coast Veterinary Conference.

Nahla, R. E. (1989): Some studies on ectoparasitic infestation in freshwater fish. Thesis.Facult.Vet.Med. Cairo University.

Okonji, V.A. and Akolisa, O. (2005): Growth performance of Oreochromis niloticus in combination with Claries Catfishes in monoculture and polyculture.Tropical, FreshWater Biology. Vol 14: 117- 132.

Prithwiraj, J. S. and Barat, C. (2008): Fish production, water quality and bacteriological parameters of Koi Carp ponds under live food and manure based management regimes. Zoological Research, Apr. 29(2): 165-173

Saed, S. M. and Sakr, S. F. (2009): Studies on water quality, culture performance and health aspects of nile 
tilapia (Oreochromis niloticus) in fresh and brackish water fish sarms. Abbasa Int.J.Aqua. (1).2009

Snedecor, G.W. and Cochran, W.G. (1989): Statistical methods. 8 th Ed. Iowa State University press, Ames, IA.

Wickens, J. F. (2006): Water quality requirements for intensive aquaculture: A review. PP $17-37$ in: proc. World Symposium on aquaculture in heated effluents and recirculation systems

Wrigley, T. J.; Toerien, D. F and Gaigher, I. G. (1988):

Fish production in small oxidation ponds. Water Res .22 (10) $1279-1285$.

Yang, Y. (1999): Modeling growth of Nile tilapia ( Oreochromis niloticus ) in a cage - cum-pond integrated culture system. Aquacultural Engineering, 21: 113- 133.

\section{تأثير نوعية المياه على إنتاجية الأسماك}

أجريت الفحوصات الفيزيائية والكيميائية والبكتريولوجية لعينـات مياه أخذت بالتسـاوى من أحواض التربية في ثلاث مئل مزارع سمكية

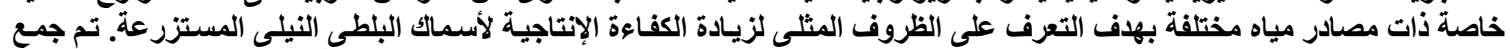

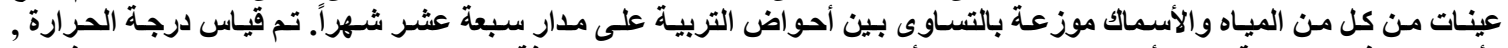

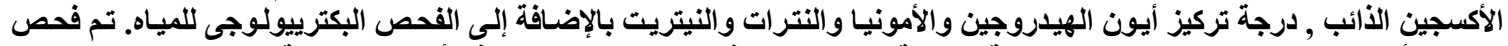

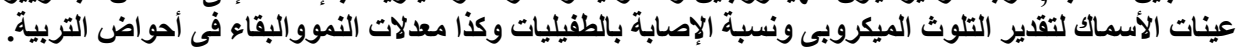

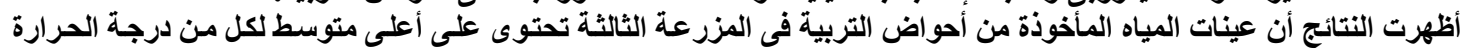

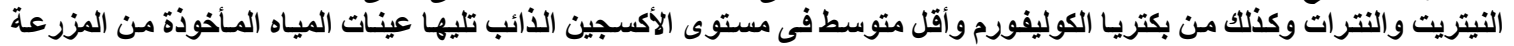

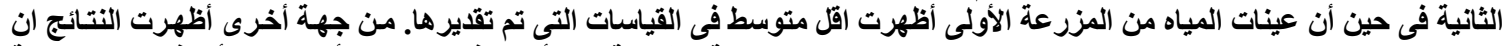

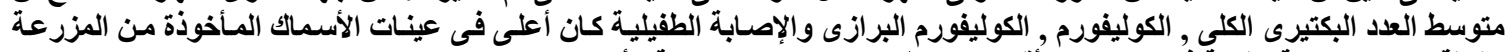

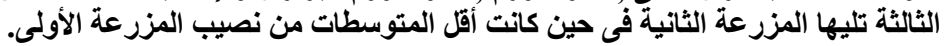

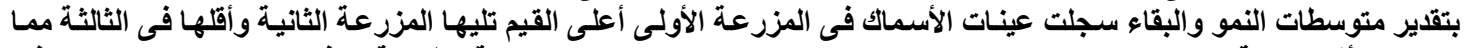

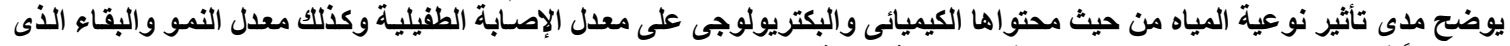

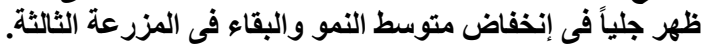

